\author{
St udia P hilosophic a \\ Wr a t is l a vi e n s i a \\ vol. XV, fasc. $3(2020)$
}

https://doi.org/10.19195/1895-8001.15.3.7

\author{
EWA CHUDOBA \\ ORCID: 0000-0002-0089-8258 \\ Uniwersytet Jagielloński
}

\title{
Nie na Parnasie, czyli sztuka w ujęciu ewolucyjnym
}

Jerzy Luty, Sztuka jako adaptacja. Uniwersalizm w estetyce ewolucyjnej, Aureus, Kraków 2019, il., ss. 223 wraz z indeksem.

Jerzy Luty jest od wielu lat promotorem i entuzjastą mało rozpowszechnionego w Polsce nurtu — estetyki ewolucyjnej. Swoje ambitne zainteresowania prezentuje szerokiej publiczności na znanym portalu Racjonalista.pl, gdzie można przeczytać jego teksty i tłumaczenia $\mathrm{z}$ anglosaskich estetyków ewolucyjnych. Z równą energią działa także na polu akademickim. Jest jedyną osobą w kraju mającą pełną znajomość estetyki ewolucyjnej i kompetencje do jej krytycznej prezentacji. Taki też jest cel jego panoramicznej monografii Sztuka jako adaptacja, wydanej w 2019 roku w Aureusie.

Główna teza książki ma walor klasyczny i głosi, że sztuka jest adaptacyjną sprawnością gatunku Homo sapiens. Innymi słowy jej powszechne opanowanie przez te właśnie hominidy przyczyniło się do sukcesu ewolucyjnego człowieka rozumnego. Co więcej, zamiłowanie do sztuki, najszerzej rozumianej, jest częścią naszej obecnej postmodernistycznej osobowości, gdyż jest to niezbywalne dziedzictwo po paleolicie. Jerzy Luty twierdzi ponadto, że otworzenie estetyki w obliczu jej kryzysu (czy też już postkryzysu) na schemat pojęciowy ewolucjonizmu przyczyni się do umocnienia dyscypliny i pozwoli łatwiej określić jej tożsamość. O ile pierwsza teza nie budzi sprzeciwu, o tyle druga — już tak. Wydaje się bowiem, że nie uda się odwrócić transferu estetyki z dziedziny filozoficznej do szeroko pojętego kulturoznawstwa. Ukazywanie biologicznych podstaw sztuki nie odwróci „uempirycznienia” estetyki, co uczyniło z niej studia kulturowo-socjologiczne. Może jednak autorowi chodzi o jeszcze inny rodzaj umocnienia, taki, który uczyni z estetyki 
dyscyplinę socjobiologiczną czy część evolutionary studies? Pochylmy się więc nad jego stanowiskiem.

Przede wszystkim podejście Lutego jest wielowymiarowe. Nie odżegnując się od patronatu Darwina, zbliża się do obecnych ewolucyjnych ujęć sztuki, które w Polsce są dopiero odkrywane przez rzesze inteligencji. Mam na myśli przede wszystkim dwa nazwiska: Duttona i Dissanayake. Sława tego pierwszego dotarła do naszego kraju dzięki Lutemu, który pozostawał jego admiratorem, i co najważniejsze poświęcił część swojego życia, aby przybliżyć jego myśl i postać polskim inteligentom.

W zeszłym roku ukazało się opus magnum Duttona w Copernicus Centre Press. Jest nim Instynkt sztuki w tłumaczeniu właśnie polskiego badacza. Książka święci triumf w Polsce i otwiera horyzonty miłośnikom sztuki zogniskowane do tej pory wokół zupełnie odmiennego stylu myślenia, który można nazwać europejskim. Denis Dutton, Amerykanin i naturalizowany Nowozelandczyk, wprowadza nas w kategorie, które nie były akcentowane przez rodzimych estetyków. Jest nią przede wszystkim uniwersalistyczne podejście do sztuki, czyli takie, które ujawnia jej absolutną powszechność, jawność i dostępność. To aspekt, który umykał uwadze europejskiej estetyki, a pojawiał się na przykład w amerykańskiej estetyce pragmatycznej. Innymi słowy ludzie we wszystkich kulturach realizują się artystycznie i/ lub estetycznie. Rozróżnienie to rozumiałabym też w możliwie najszerszy sposób, a mianowicie taki, że część uczestników społeczeństw sztukę wytwarza, a część ją odbiera czy konsumuje. Jest również część wspólna, czyli ludzie, którzy wytwarzają sztukę i również się nią napawają. Taki stan rzeczy ma źródło w głównej hipotezie estetyki ewolucyjnej, a mianowicie że sztuka jest pewnym mechanizmem przystosowawczym i generalnie, aby sparafrazować Nietzschego, służy życiu, a nie je osłabia, stąd rozwija się pod każdą szerokością geograficzną. Ów mechanizm ujawnił swą moc w epoce prehistorycznej zwanej paleolitem i został w przedstawicielach gatunku jako element ludzkiej osobowości.

Tak najogólniej można sparafrazować credo Duttona, które Luty zestawia z innymi koncepcjami. Do jego wzmocnienia warto jeszcze zaznaczyć, że stanowisko ewolucyjne w estetyce nie odróżnia tego, co estetyczne od tego, co artystyczne, ale raczej widzi te kategorie jako składowe jednego procesu — zajmowania się sztuką. Podobnie zresztą dzieje się w estetyce pragmatycznej (którą nie będę się bliżej zajmować), co wynika z ewolucyjnych podstaw obu estetyk.

Ciekawa jest również wspomniana Ellen Dissanayake - pionierka nowoczesnej estetyki ewolucyjnej. Amerykańska badaczka twierdzi, że sztuka jest o tyle adaptacją, o ile jest konkretnym zachowaniem, które nazywa ona artyfikacją. Istnienie samego przedmiotu sztuki nie jest dla niej podstawowe w procesie wytworzenia się mechanizmu adaptacyjnego. Najważniejsze pozostaje to, co do niego prowadzi, a więc potrzeba ludzi do nadawania czemuś szczególnego znaczenia. Źródła tej potrzeby są prehistoryczne. Ludzie paleolityczni artyfikowali, aby zwyczajny przedmiot połączyć z nadzmysłową sferą, co miało gwarantować pomyślność działań przedsięwziętych przez grupę plemienną/koczowniczą. Artyfikacja była zatem zrytualizowana i kolektywna, co miało wzmacniać solidarność owej grupy i poczucie więzi (s. 83). Dzisiaj działania artyfikacyjne są częściej zindywidualizowane, 
z wyjątkami w postaci kultur kolektywnych i pozazachodnich lub wielkich przedsięwzięć artystycznych, wymagających pracy grupowej. Jerzy Luty omawia mniej lub bardziej szczegółowo współczesne sztuki oparte na mądrości plemiennej (na przykład garncarstwo), korzystając z badań antropologów i etnologów.

Jak widzimy, badania estetyczne obecnie, w szczególności dzięki przyjętemu ewolucjonizmowi, rozwijają się dzięki szerokiemu ujmowaniu swojego zakresu. Nie będzie przesadą stwierdzenie, że wszelakie czynności dekoracyjne (i inne mające na celu działanie artystyczne) już podpadają pod zakres słów sztuka i estetyka. Obszerne spektrum pojęciowe sprawia, że badacz pracujący w paradygmacie ewolucyjnym ma duże pole problemów, z którego może wybierać. Jerzy Luty prezentuje w swej monografii prawdziwe bogactwo tematyczne. Zajmuje się również, poza tu przedstawionymi zagadnieniami, sztuką dzieci i jej znaczeniem w ontogenezie, problematyką sztuki zwierząt, międzykulturowym rozumieniem, a raczej niezrozumieniem sztuki, fałszerstwem czy pojęciem kunsztu. Przyjęty paradygmat ma także swą specyfikę, a jest nią mianowicie ograniczona perspektywa instytucjonalna w ściśle zachodnim sensie.

Miłośników współczesnych rozważań o sztuce w kontekście muzeów i galerii oraz ich społecznego znaczenia może zastanawiać brak tego wątku, choć nie brakuje kontrargumentów samego Danto (s. 71). Fakt, że Jerzy Luty nie analizuje estetyki i sztuki na poziomie instytucji w znaczeniu zachodnim, wynika rzecz jasna z uwikłań w adaptacjonizm. Nie jest to jednak pełny obraz sytuacji. Czyż bowiem u źródeł istnienia instytucji nie stoi jakiś mechanizm adaptacyjny? Wszak krajom, które mają dobrze rozwinięte instytucje, lepiej się powodzi niż krajom bez sprawnie działających instytucji, jak to ma miejsce w wielu państwach afrykańskich. Wydaje mi się, że główną przyczyną, że wątek ten nie wybrzmiewa w pełni, jest to, że ewolucyjna teoria sztuki to niewyrażona wprost krytyka instytucjonalnego rozumienia sztuki, obecnie dominującego. Jest ono jednak niewystarczające dla wyjaśnienia głęboko- i ogólnoludzkiego fenomenu sztuki, ponieważ w centrum stawia eksperta uznającego coś za sztukę. Ujęcie ewolucyjne jest zainteresowane zsocjalizowaną jednostką, która na każdym kroku potrzebuje sztuki i z niej korzysta: czy to w ramach popkultury, czy w ramach społecznego rytuału, w osobistym przeżyciu jakiejś szczególnej chwili czy nadając czemuś znaczenie. Jednostka ta działa zawsze jako część społeczeństwa, uosabiając jej ducha. W ujęciu instytucjonalnym to instytucja uosabia ducha społeczeństwa, a jednostka jest im poddana; tu sztuka jest na Parnasie, w perspektywie ewolucyjnej w naszych umysłach i sercach.

Można też postawić sprawę inaczej: estetyka ewolucyjna nadaje równowagi debacie estetycznej, jest swoistą odtrutką na propozycję Dickiego, Danto i innych, która zdaje się nie mieć godnej konkurencji. Estetyka ewolucyjna wraz z neuroestetyką ożenioną z pragmatyzmem tworzyłyby drugi filar, obok estetyki analitycznej i instytucjonalnej, współczesnych rozważań o sztuce. Z jednej strony recenzowane przeze mnie ujęcie kładzie nacisk na prywatność, różnorodność i powszechność doświadczenia estetycznego, które nie musi się przekładać na żaden aspekt instytucjonalny. (Estetyka ewolucyjna zajmuje się wątkami drugorzędowymi dla instytucjonalnego rozumienia sztuki). Z drugiej strony nie jest tak, że Jerzy Luty nie prezentuje wcale wątku instytucjonalnego. Wszak podejmuje polemikę z estetykami 
analitycznymi, zagłębia się w rozmaite meandry definicji sztuki czy nie oszczędza krytyków zajmujących się sztukami plemiennymi pozazachodnimi.

Trzeba jednak jeszcze raz podkreślić, że sercem monografii są dociekania na temat adaptacyjności sztuki i rozważań tych nie pozostawia Jerzy Luty bez metaanalizy. Ważnym wątkiem monografii jest przedstawienie sporu o adaptacyjne rozumienie sztuki. Czym w istocie ona jest? Zarówno sztuka, jak i adaptacja. Problemy z trudnością w definiowaniu sztuki są motywem przewodnim całej dwudziestowiecznej estetyki i brak konsensusu w tej sprawie żywi trwający obecnie postkryzys dyscypliny. Jerzy Luty przyjmuje w książce panoramiczne rozumienie sztuki, którego nie znali ani Roman Ingarden, ani Władysław Tatarkiewicz, rezygnując z jej tradycyjnego genus proximum. Taki zabieg jest konieczny przy przyjętym horyzoncie intelektualnym. Sztuka jest albo adaptacją biologiczną, albo efektem ubocznym takiej adaptacji lub zjawiskiem kulturowym. Trzecie stanowisko zapewne interesowałoby autora o tyle, o ile połknąłby pragmatystyczny bakcyl do wywodzenia, iż kultura jest kontynuacją rozwoju biologicznego, więc mieści się w paradygmacie naturalistycznym. To stanowisko jednak najmniej zajmuje Lutego. Oscyluje on między dwiema pierwszymi tezami, zarzucajacc naturalizm na rzecz socjobiologizmu czy ewolucjonizmu.

Uczciwości Lutego nie można również zarzucić, że pomija mielizny stanowiska uniwersalistycznego. Relacjonuje rzetelnie eksperyment Komara i Melamida (s. 69-73), którego meandry pozostawiam do odkrycia czytelnikom, ale zabrakło w tej rekonstrukcji trzeźwego krytycyzmu. Byłby on przydatny, gdyż doniosłość tego eksperymentu jest dla nas, Europejczyków, dość przewrotna: doskonale wyjaśnia on genezę kiczu. Zastanawiające jest, że w książce o mocnej tezie powszechnościowej autor nie przeanalizował przyczyn umiłowania tandety, które występuje wszędzie tam, gdzie sama sztuka, a poświecił miejsce dość marginalnemu zagadnieniu, jakim jest jej fałszowanie (s. 133-159). Chociaż może w dobie plagiatów ważniejsze jest zajęcie się fake-sztuką niż pop-sztuką mas?

Odwaga estetyczna autora ujawnia się w poruszeniu zjawiska, jakim jest sztuka zwierząt (s. 161-174). Wywołuje ona duże emocje, obalając aksjomat o tym, że sztukę tworzą jedynie ludzie. Otóż nie. Nie od dziś wiadomo, że zwierzęta posługują się narzędziami (odkryła to już Jane Goodall w latach sześćdziesiątych XX wieku), zatem krok do przyznania im autorstwa w dziedzinie sztuki nie jest wcale krokiem milowym, lecz dość naturalną konsekwencją. Warto może podejść do sztuki zwierząt przez naszą zwierzęcą część i dziedzictwo — jesteśmy (zarówno my, jak i zwierzęta) w końcu podmiotami i przedmiotami stale dokonującej się ewolucji, czy tego chcemy, czy nie. Podlega jej wraz z biologią również warstwa kulturowa.

Na koniec trzeba powiedzieć najistotniejszą rzecz: podejście Lutego jest głęboko humanistyczne. Powoduje nim ciekawość badawcza oddająca głos wszystkim zainteresowanym w prezentowanej debacie o adaptacyjności sztuki. Nie daje się też zwieść żadnemu głosowi, który „na pewno” uratuje estetykę przed jej rozpłynięciem się w powietrzu. W gruncie rzeczy Jerzy Luty wierzy, że nie potrzebuje ona żadnego pozytywistycznego zbawienia, bo zawsze obroni się sama. I znów podstawą takiego przekonania jest głęboki humanizm autora, zasadzający się na tym, że sztukę, a wraz z nią jej teorię, uratują jej użytkownicy — więc my wszyscy, którzy 
jesteśmy nie tylko zjadaczami chleba, ale konsumentami jej zawartości, gdyż mamy to w swoim uposażeniu poznawczym.

Książka jest godna szczególnego polecenia nie tylko z powodu rzetelności badawczej i harmonijnego sposobu konstruowania wywodu, które mogą predestynować Lutego do bycia intelektualnym wnukiem Vetulaniego (także ze względu na rozwinięcie tezy o adaptacyjności sztuki podzielanej przez neurobiologa). Najważniejszą sprawą pozostaje język, jakim monografia jest napisana. Jej czytelnicy mogą z przyjemnością oddać się lekturze, nie narażając się na dysonans poznawczy: teza o uniwersalizmie sztuki jest opowiedziana $\mathrm{w}$ taki sposób, że odbiorcy poczują się pełnowartościowymi uczestnikami tego świata. Innymi słowy osiągnął Jerzy Luty równowagę między prezentowanymi tezami a formą ich wypowiedzenia. Taki rodzaj syntonii wzmacnia główne przesłanie monografii, która tym samym ochrania estetykę przed bolączkami postkryzysu. Może, droga estetyko, nie jest tak najgorzej, skoro powstają takie książki? 